\title{
Productivity and Quality of Wheat (Triticum aestivum L.) as Influenced by Different Levels of Potassium and Nitrogen Fertilization
}

\author{
Tangit Longkumer* and Thomas Abraham \\ Sam Higginbottom University of Agriculture, Technology and Sciences, \\ Allahabad, 211007, Uttar Pradesh, India \\ *Corresponding author
}

\begin{tabular}{|c|}
\hline Keywords \\
\hline $\begin{array}{l}\text { Productivity, } \\
\text { Potassium, } \\
\text { Nitrogen, Quality, } \\
\text { Wheat }\end{array}$ \\
\hline Article Info \\
\hline $\begin{array}{l}\text { Accepted: } \\
\text { 20 July } 2018 \\
\text { Available Online: } \\
\text { 10 August } 2018\end{array}$ \\
\hline
\end{tabular}

Keywords

Productivity,

Potassium,

Nitrogen, Quality,

Wheat

Article Info

Accepted:

Available Online:

\section{Introduction}

Wheat (Triticum aestivum L.) is the most important and widely cultivated food crop in the world. In India, wheat is the second important cereal crop, first being Rice. It contributes nearly one-third of the total food grains production. It is consumed mostly in the form of bread as "Chapati". Wheat straw is used for feeding cattle. Wheat contains more protein than other cereal and has a relatively high content of niacin and thiamine. It is basically concerned in providing the
A field experiment was conducted at Crop Research Farm (CRF), SHUATS, Allahabad, during the Rabi season of 2017 with 12 treatments replicated thrice in randomized block design, to study the productivity and quality of wheat (Triticum aestivum L.) as influenced by different levels of potassium and nitrogen fertilization. Yield attributes and yield exerted significant variation due to application of different levels of potassium and nitrogen. The result revealed that treatment $\mathrm{T}_{8}\left(60 \mathrm{~kg} \mathrm{~K}_{2} \mathrm{O}+\right.$ $\left.120 \mathrm{~kg} \mathrm{~N} \mathrm{ha}^{-1}\right)$ was found to be maximum for no. of grains spike ${ }^{-1}(52.13)$ and test weight $(49.87 \mathrm{~g})$. Grain and Straw yield $\left(6.30 \mathrm{t} \mathrm{ha}^{-1}\right.$ and $8.94 \mathrm{t} \mathrm{ha}^{-1}$ respectively) were found to be highest in treatment $\mathrm{T}_{11}\left(90 \mathrm{~kg} \mathrm{~K}_{2} \mathrm{O} \mathrm{ha}^{-1}+120 \mathrm{~kg} \mathrm{~N} \mathrm{ha}^{-1}\right)$. Regarding the grain quality of wheat, the highest protein content $(11.81 \%)$ was recorded from treatment $\mathrm{T}_{8}\left(60 \mathrm{~kg} \mathrm{~K}_{2} \mathrm{O}+120 \mathrm{~kg} \mathrm{~N} \mathrm{ha}^{-1}\right)$. 
Potassium $(\mathrm{K})$ is the third most important macronutrient required for plant growth, after nitrogen $(\mathrm{N})$ and phosphorus $(\mathrm{P})$, and is one of the principle plant nutrients underpinning crop yield production and quality determination. As potassium is involved in many physiological processes, its impact on water relations, photosynthesis, assimilate transport, and enzyme activation can have direct consequences on crop productivity (Pettigrew, 2008) by regulating the opening and closing of stomata and therefore regulating moisture loss from the plant. For this reason, potassium is colloquially known as "poor-man's irrigation" because it assists crops to achieve yields more effectively (SQO, 2015). The requirement for $\mathrm{K}$ varies from plant to plant and from species to species. For example, wheat requires $\mathrm{K}$ for optimal growth and development while adequate $\mathrm{K}$ results in superior quality of the whole plant due to improved photosynthetic efficiency, increased resistance to some diseases, greater water use efficiency, and helps to maintain a normal balance between carbohydrates and proteins. Sufficient K results in stronger wheat straw and assists in grain filling (Agri-News, 2012).Balanced fertilizers are essential for the enhancement of the yield. Nitrogen fertilizer is basically used for better seed development, seed maturity and grain production. Nitrogen is most often the limiting nutrient for plant growth and development (Andrews et al., 2004). Grain yield and quality of wheat is improved by the foliar application of nitrogen fertilizer, Rozsypal (1989).Therefore, an experiment was conducted to study performance of wheat with different levels of potassium and nitrogen fertilization in terms of yield attributes, yield and quality.

\section{Materials and Methods}

The experiment was carried out at Crop Research Farm, Department of Agronomy,
Naini Agricultural Institute, SHUATS, Allahabad (U.P.).

The area is situated on the south of Allahabad on the right hand of rivers Yamuna at Rewa Road at a distance of about $7 \mathrm{~km}$ of Allahabad city. Allahabad has sub-humid sub-tropical climate with the monsoon commencing from July and withdrawing by the end of September. The rainfall is unevenly distributed and most of it is received between July and September.

Apart from this, a few winter and summer showers are also received. The soil of the experimental field was sandy loam in texture with $\mathrm{pH} 7.6$, low in organic carbon $0.42 \%$, available $\mathrm{P} 13.50 \mathrm{~kg} / \mathrm{ha}$ and available $\mathrm{K}$ $257.04 \mathrm{~kg} / \mathrm{ha}$. This experiment was conducted in year 2017-18 during the Rabi season and wheat variety 'SHIATS-W6' was sown on $15^{\text {th }}$ November, 2017.

The experiment consisted of four potassium levels, viz. 0 (Control), 45, 60 and $90 \mathrm{~kg} \mathrm{~K}_{2} 0$ /ha and three nitrogen levels, viz. 90, 120 and $150 \mathrm{~kg} \mathrm{~N} /$ hawith 12 treatments replicated thrice in randomized block design.

A common dose of phosphorus @ $60 \mathrm{~kg} / \mathrm{ha}$ was applied through single super phosphate, at the time of sowing. Half of nitrogen was applied as basal dressing at sowing and rest half of nitrogen was top-dressed at the time of first irrigation at the crown root initiation stage of crop. The crop received six uniform irrigations. Potassium and nitrogen was applied through muriate of potash and urea respectively, as per treatments. Other agronomic management practices were followed as per the standard recommendation. Crop was harvested in the last week of March. The data on various, yield attributes and yield were recorded in different treatments. All the data were statistically analyzed. 


\section{Results and Discussion}

\section{Yield attributes}

\section{Number of grains per spike}

Number of grains spike ${ }^{-1}$ is an important yield contributing parameter and has a direct bearing on the final grain yield of wheat. The data as presented in Table 1 showed that there was a significant difference within the treatments for number of grains spike $^{-1}$. Treatment $\mathrm{T}_{8}\left(60 \mathrm{~kg} \mathrm{~K}_{2} \mathrm{O} \mathrm{ha}^{-1}+120 \mathrm{~kg} \mathrm{~N}\right.$ $\mathrm{ha}^{-1}$ ) recorded significant and highest number of grains spike ${ }^{-1}$ (52.13). However, except for control, all other treatments were statistically at par with treatment $\mathrm{T}_{8}\left(60 \mathrm{~kg} \mathrm{~K}_{2} \mathrm{O} \mathrm{ha}^{-1}+120\right.$ $\left.\mathrm{kg} \mathrm{N} \mathrm{ha}{ }^{-1}\right)$. Application of potassium improved the number of grains spike ${ }^{-1}$ which might be due to the favourable effects of potassium on nutrient uptake, photosynthetic activity, improving its mobilization (Arif et al., 2017). These results are in close agreement with the findings of Jan et al., 2012. Meynard, 1987 reported that the number of grains spike ${ }^{-1}$ is the best indicator of wheat response to nitrogen and that grains spike $^{-1}$ is negatively affected by nitrogen deficiency. Iqtidar et al., (2006) also reported similar findings.

\section{Test weight}

The data as presented in Table 1 revealed that potassium and nitrogen fertilization had a significant effect on grain weight. Treatment $\mathrm{T}_{8}\left(60 \mathrm{~kg} \mathrm{~K}_{2} \mathrm{O} \mathrm{ha}^{-1}+120 \mathrm{~kg} \mathrm{~N} \mathrm{ha}^{-1}\right)$ resulted in significant and highest increase in test weight $(49.87 \mathrm{~g})$. However, treatment $\mathrm{T}_{4}$ $\left(45 \mathrm{~kg} \mathrm{~K}_{2} \mathrm{O} \mathrm{ha}{ }^{-1}+90 \mathrm{~kg} \mathrm{~N}^{-1}\right), \mathrm{T}_{5}\left(45 \mathrm{~kg} \mathrm{~K}_{2} \mathrm{O}\right.$ $\left.\mathrm{ha}^{-1}+120 \mathrm{~kg} \mathrm{~N} \mathrm{ha}^{-1}\right), \mathrm{T}_{9}\left(60 \mathrm{~kg} \mathrm{~K}_{2} \mathrm{O} \mathrm{ha}{ }^{-1}+150\right.$ $\left.\mathrm{kg} \mathrm{N} \mathrm{ha}{ }^{-1}\right), \mathrm{T}_{11}\left(90 \mathrm{~kg} \mathrm{~K}_{2} \mathrm{O} \mathrm{ha}^{-1}+120 \mathrm{~kg} \mathrm{~N}\right.$ $\left.\mathrm{ha}^{-1}\right)$ and $\mathrm{T}_{12}\left(90 \mathrm{~kg} \mathrm{~K}_{2} \mathrm{O} \mathrm{ha}^{-1}+150 \mathrm{~kg} \mathrm{~N} \mathrm{ha}^{-1}\right)$ were found to be statistically at par with $\mathrm{T}_{8}$ $\left(60 \mathrm{~kg} \mathrm{~K}_{2} \mathrm{O} \mathrm{ha}{ }^{-1}+120 \mathrm{~kg} \mathrm{~N} \mathrm{ha}^{-1}\right)$. Adequate potash supply increased the photosynthetic rate of the crop and material transition in phloem, grain filling process and facilitates the quick transportation of nutrients and assimilates towards the grain which increase the test weight (Akhter, 2016). It was observed that the crop receiving higher levels of nitrogen fertilizer produced bolder grains and hence higher test weight was obtained (Farooq et al., 2018).

\section{Yield}

Grain and straw yield of wheat increased significantly with the application of potassium and nitrogen fertilization. Treatment $\mathrm{T}_{11}(90$ $\mathrm{kg} \mathrm{K} \mathrm{K}_{2} \mathrm{O} \mathrm{ha}{ }^{-1}+120 \mathrm{~kg} \mathrm{~N} \mathrm{ha}^{-1}$ ) resulted in significant and highest increase in grain and straw yield $\left(6.30 \mathrm{t} \mathrm{ha}^{-1}\right.$ and $8.94 \mathrm{t} \mathrm{ha}^{-1}$ respectively). However, treatment $\mathrm{T}_{7}(60 \mathrm{~kg}$ $\left.\mathrm{K}_{2} \mathrm{O} \mathrm{ha}^{-1}+90 \mathrm{~kg} \mathrm{~N} \mathrm{ha}^{-1}\right)$ and $\mathrm{T}_{10}\left(90 \mathrm{~kg} \mathrm{~K}_{2} \mathrm{O}\right.$ $\mathrm{ha}^{-1}+90 \mathrm{~kg} \mathrm{~N} \mathrm{ha}{ }^{-1}$ ) were found to be statistically on a par with treatment $T_{11}(90 \mathrm{~kg}$ $\mathrm{K}_{2} \mathrm{O} \mathrm{ha}^{-1}+120 \mathrm{~kg} \mathrm{~N} \mathrm{ha}^{-1}$ ). The increased yield with the potassium fertilization might be due to increased availability, absorption and translocation of potassium nutrient. As potassium is essential for grain development, the favourable effect of high doses of potassium on yield attributes was mainly responsible for higher grain and straw yields (Singh et al., 2015) (Table 2).

The increase in grain yield with the application of nitrogen can be ascribed to better plant growth and dry matter production due to higher photosynthetic area (Satyanarayana et al., 2017). The results were in corroboration with the findings of Sharma and Manohar, 2002. Increase in straw yield with the application of nitrogen probably came through favourable influence of nitrogen on growth parameters in terms of plant height, number of tillers, dry matter production and LAI (Patra and Ray, 2018). Similar findings were reported by Beheraa and Rautaray, 2010. 
Table.1 Effect of potassium and nitrogen fertilization on yield attributes and yield of wheat

\begin{tabular}{|c|c|c|c|c|c|}
\hline & \multirow[t]{2}{*}{ Treatment } & \multicolumn{2}{|c|}{ Yield attributes } & \multicolumn{2}{|c|}{ Yield } \\
\hline & & $\begin{array}{c}\text { No. of grains } \\
\text { spike }^{-1}\end{array}$ & $\begin{array}{c}\text { Test weight } \\
\text { (g) }\end{array}$ & $\begin{array}{c}\text { Grain yield } \\
\left(t \text { ha }^{-1}\right)\end{array}$ & $\begin{array}{c}\text { Straw yield } \\
\left(\mathbf{t ~ h a}^{-1}\right)\end{array}$ \\
\hline $\mathbf{T}_{1}$ & Control+ $90 \mathrm{~kg} \mathrm{~N} \mathrm{ha}^{-1}$ & 42.13 & 45.67 & 4.77 & 6.82 \\
\hline $\mathbf{T}_{2}$ & Control + $120 \mathrm{~kg} \mathrm{~N} \mathrm{ha}^{-1}$ & 34.13 & 46.00 & 4.55 & 6.31 \\
\hline $\mathbf{T}_{\mathbf{3}}$ & Control + $150 \mathrm{~kg} \mathrm{~N} \mathrm{ha}^{-1}$ & 42.80 & 46.67 & 3.86 & 5.37 \\
\hline $\mathbf{T}_{4}$ & $45 \mathrm{~kg} \mathrm{~K}_{2} \mathrm{O} \mathrm{ha}{ }^{-1}+90 \mathrm{~kg} \mathrm{~N} \mathrm{ha}^{-1}$ & 48.13 & 48.00 & 3.93 & 5.37 \\
\hline $\mathbf{T}_{\mathbf{5}}$ & $45 \mathrm{~kg} \mathrm{~K}_{2} \mathrm{O} \mathrm{ha} \mathrm{ha}^{-1}+120 \mathrm{~kg} \mathrm{~N} \mathrm{ha}^{-1}$ & 50.80 & 48.67 & 4.71 & 6.44 \\
\hline $\mathbf{T}_{6}$ & $45 \mathrm{~kg} \mathrm{~K}_{2} \mathrm{O} \mathrm{ha}{ }^{-1}+150 \mathrm{~kg} \mathrm{~N} \mathrm{ha}^{-1}$ & 45.07 & 47.00 & 4.84 & 6.74 \\
\hline $\mathbf{T}_{7}$ & $60 \mathrm{~kg} \mathrm{~K}_{2} \mathrm{O} \mathrm{ha}{ }^{-1}+90 \mathrm{~kg} \mathrm{~N} \mathrm{ha}^{-1}$ & 50.00 & 47.33 & 5.46 & 7.79 \\
\hline $\mathbf{T}_{8}$ & $60 \mathrm{~kg} \mathrm{~K}_{2} \mathrm{O} \mathrm{ha}^{-1}+120 \mathrm{~kg} \mathrm{~N} \mathrm{ha}^{-1}$ & 52.13 & 49.87 & 4.08 & 5.59 \\
\hline $\mathbf{T}_{9}$ & $60 \mathrm{~kg} \mathrm{~K}_{2} \mathrm{O} \mathrm{ha}{ }^{-1}+150 \mathrm{~kg} \mathrm{~N} \mathrm{ha}^{-1}$ & 43.00 & 48.00 & 4.79 & 5.95 \\
\hline $\mathbf{T}_{10}$ & $90 \mathrm{~kg} \mathrm{~K}_{2} \mathrm{O} \mathrm{ha}^{-1}+90 \mathrm{~kg} \mathrm{~N} \mathrm{ha}^{-1}$ & 43.53 & 47.33 & 5.31 & 7.29 \\
\hline $\mathbf{T}_{11}$ & $90 \mathrm{~kg} \mathrm{~K}_{2} \mathrm{O} \mathrm{ha}^{-1}+120 \mathrm{~kg} \mathrm{~N} \mathrm{ha}^{-1}$ & 49.73 & 48.00 & 6.30 & 8.94 \\
\hline \multirow[t]{5}{*}{$\mathbf{T}_{12}$} & $90 \mathrm{~kg} \mathrm{~K}_{2} \mathrm{O} \mathrm{ha}^{-1}+150 \mathrm{~kg} \mathrm{~N} \mathrm{ha}^{-1}$ & 44.00 & 48.67 & 5.07 & 6.92 \\
\hline & F test & $\mathrm{S}$ & $\mathrm{S}$ & $\mathrm{S}$ & $\mathrm{S}$ \\
\hline & $\operatorname{SEd}( \pm)$ & 4.47 & 1.12 & 0.58 & 0.94 \\
\hline & $\mathrm{CD}(\mathrm{P}=0.05)$ & 9.27 & 2.31 & 1.21 & 1.94 \\
\hline & $\mathrm{CV}(\%)$ & 12.04 & 2.86 & 14.97 & 7.61 \\
\hline
\end{tabular}


Table. 2 Effect of potassium and nitrogen fertilization on grain protein

\begin{tabular}{|l|l|c|}
\hline & \multicolumn{1}{|c|}{ Treatments } & Grain Protein (\%) \\
\hline $\mathbf{T}_{\mathbf{1}}$ & Control+ $90 \mathrm{~kg} \mathrm{~N} \mathrm{ha}^{-1}$ & 7.66 \\
\hline $\mathbf{T}_{\mathbf{2}}$ & Control $+120 \mathrm{~kg} \mathrm{~N} \mathrm{ha}^{-1}$ & 7.88 \\
\hline $\mathbf{T}_{\mathbf{3}}$ & Control $+150 \mathrm{~kg} \mathrm{~N} \mathrm{ha}^{-1}$ & 10.94 \\
\hline $\mathbf{T}_{\mathbf{4}}$ & $45 \mathrm{~kg} \mathrm{~K}_{2} \mathrm{O} \mathrm{ha}^{-1}+90 \mathrm{~kg} \mathrm{~N} \mathrm{ha}^{-1}$ & 10.28 \\
\hline $\mathbf{T}_{\mathbf{5}}$ & $45 \mathrm{~kg} \mathrm{~K}_{2} \mathrm{O} \mathrm{ha}^{-1}+120 \mathrm{~kg} \mathrm{~N} \mathrm{ha}^{-1}$ & 11.38 \\
\hline $\mathbf{T}_{\mathbf{6}}$ & $45 \mathrm{~kg} \mathrm{~K}_{2} \mathrm{O} \mathrm{ha}^{-1}+150 \mathrm{~kg} \mathrm{~N} \mathrm{ha}^{-1}$ & 11.68 \\
\hline $\mathbf{T}_{\mathbf{7}}$ & $60 \mathrm{~kg} \mathrm{~K}_{2} \mathrm{O} \mathrm{ha}^{-1}+90 \mathrm{~kg} \mathrm{~N} \mathrm{ha}^{-1}$ & 9.19 \\
\hline $\mathbf{T}_{\mathbf{8}}$ & $60 \mathrm{~kg} \mathrm{~K}_{2} \mathrm{O} \mathrm{ha}^{-1}+120 \mathrm{~kg} \mathrm{~N} \mathrm{ha}^{-1}$ & 11.81 \\
\hline $\mathbf{T}_{\mathbf{9}}$ & $60 \mathrm{~kg} \mathrm{~K}_{2} \mathrm{O} \mathrm{ha}^{-1}+150 \mathrm{~kg} \mathrm{~N} \mathrm{ha}^{-1}$ & 10.50 \\
\hline $\mathbf{T}_{\mathbf{1 0}}$ & $90 \mathrm{~kg} \mathrm{~K}_{2} \mathrm{O} \mathrm{ha}^{-1}+90 \mathrm{~kg} \mathrm{~N} \mathrm{ha}^{-1}$ & 9.63 \\
\hline $\mathbf{T}_{\mathbf{1 1}}$ & $90 \mathrm{~kg} \mathrm{~K}_{2} \mathrm{O} \mathrm{ha}^{-1}+120 \mathrm{~kg} \mathrm{~N} \mathrm{ha}^{-1}$ & 10.72 \\
\hline $\mathbf{T}_{\mathbf{1 2}}$ & $90 \mathrm{~kg} \mathrm{~K}_{2} \mathrm{O} \mathrm{ha}^{-1}+150 \mathrm{~kg} \mathrm{~N} \mathrm{ha}^{-1}$ & 11.38 \\
\hline
\end{tabular}

*Data on grain protein content are not subjected to statistical analysis

\section{References}

Agri-News. 2012. E-Newsletter: Wheat nutrition and fertilizer requirements: potassium. Available from: http://www1.agric.gov.ab.ca/\$Departme nt/deptdocs.nsf/All/webdoc7998.

[November 4, 2015].

Andrews, M., Leap, J., Raven, J. A. and Lindsey, K. 2004. Can genetic manipulation of plant nitrogen assimilation enzymes result in increased crop yield and greater n-use efficiency? An assessment. Annals of Applied Biology145, 25- 40.

Arif, M., Tasneem, M., Bashir, F., Yaseen, G. and Anwar, A. 2017. Evaluation of different levels of potassium and zinc fertilizer on the growth and yield of wheat (Triticum aestivum L.). International Journal of Biosensors \&Bioelectonics3(2):1-5.

Beheraa, U.K. and Rautaray, S.K.2010.Effect of biofertilizers and chemical fertilizers on productivity and quality parameters of durum wheat (Triticum aestivum L.) on a vertisol of Central India. Arch. Agron. Soil Sci. 56(1): 65-72.

El-Abady, M. I., Seadh, S. E., El-Ward, Ibrahim, A. and El-Emam, A. A. M. 2009.Irrigation withholding and potassium foliar application effects on wheat yield and quality. International Journal of Sustainable Crop Production 4(4): 33- 39.

Farooq, M., Khan, I., Ahmed, S., Ilyas, N., Saboor, A., Bakhtiar, M., Khan, S., Khan, I., Ilyas, N. and Khan, A.Y. 2018. Agronomical efficiency of two wheat varieties against different levels of nitrogen fertilizer in subtropical region of Pakistan. International Journal of Environmental \& Agriculture Research 4(4): 28-36.

Guaer, M.c., Gupta, A.P. and Petkov, M. 1992. Effect of increasing nitrogen fertilization rates on grain yield and quality of winter soft wheat 
cultivars.Soils and Fert., 45:722.

Iqtidar, H., Ayyaz, K.M. and Ahmad, K.E.2006. Bread wheat varieties as influenced by different nitrogen levels. Journal of Zhejiang University Sciences7(1): 70-78.

Meynard, J.M., 1987. The analysis development for the efficiency of essays about nitrogen fertilization. Perspectives Agric.,115: 76-83.

Patra, B. and Ray, P.K. 2018. Response of wheat to various nitrogen levels under late sown condition. Journal of Experimental Agriculture International 21(1): 1-5.

Pettigrew, W.T. 2008. Potassium influences on yield and quality production for maize, wheat, soybean and cotton. Physiologia Plantarum, 133(2008): 670-681.

Prasad, R. 2012. Fertilizers and manures. Current Science 102 (6):894-898.

Rozsypal, RF. 1989. Foliar application of nitrogen and phosphorus to winter wheat. Phosphorus in late seasons on the yield and composition of wheat. Australian Journal of Experimental Agriculture30, 577-585.

Satyanarayana, M. Reddy, A.P.K., Bhatt, P.S., Reddy, S.N. and Padmaja, J. 2017.Effect of different varieties and levels of nitrogen on growth and functions of wheat. International Journal of Current Microbiology and Applied Sciences 6(8): 3435-3442.

Sharma, P.K. and Manohar, S.S.2002. Response of wheat to to nitrogen and nitrogen and sulphur and their residual effect on pearl millet. Indian Journal of Agronomy47 (4): 473-476.

Singh, V., Ali, J., Seema, Kumar, A. and Chauhan, T.M. 2015.Productivity, nutrient uptake and economics of wheat (Triticum aestivum L.) under potassium and zinc nutrition. Indian Journal of Agronomy, 60(3): 426-430

SQO(Soil Quality Organization).2015.Fact Sheets Potassium. Available from: http://www.soilquality.org.au/factsheets /potassium. [November 4, 2015].

\section{How to cite this article:}

Tangit Longkumer and Thomas Abraham. 2018. Productivity and Quality of Wheat (Triticum aestivum L.) as Influenced by Different Levels of Potassium and Nitrogen Fertilization. Int.J.Curr.Microbiol.App.Sci. 7(08): 3631-3636. doi: https://doi.org/10.20546/ijcmas.2018.708.367 